\title{
EFFECT OF DIETARY INCLUSION OF STINGING NETTLE (URTICA PARVIFLORA) ON GROWTH AND IMMUNOLOGICAL RESPONSES OF RAINBOW TROUT FRY
}

\author{
${ }^{\prime}$ Rainbow Trout Fisheries Research Station, Dhunche, Rasuwa (Nepal) \\ ${ }^{2}$ Agriculture and Forestry University, Rampur, Chitwan (Nepal) \\ ${ }^{3}$ Fisheries Research Division, Godawari, Lalitpur (Nepal)
}

SURAJ K. SINGH ${ }^{1}$, DILIP K. JHA ${ }^{2 *}$, NARAYAN PRASAD PANDIT ${ }^{2}$, NEETA PRADHAN ${ }^{3}$ and PREM TIMALSINA ${ }^{3}$

\begin{abstract}
A study was conducted in complete randomized design (CRD) to evaluate the dietary inclusion rate of Stinging nettle (Urtica parviflora) on growth and immune responses of rainbow trout fry. There were four treatments having 4 diets with control (T1), $1 \%$ (T2), $2 \%$ (T3) and $3 \%$ (T4) of stinging nettle incorporated in the diet. The treatments were replicated four times. The experiment was conducted for $90^{\text {th }}$ days from $20^{\text {th }} \mathrm{June}^{\mathrm{T}} \mathbf{1 7 ^ { \text { th } }}$ September,2018. Total harvest weight of fish in T4 $(315.95 \pm 8.11 \mathrm{~g})$ was significantly higher and different than T3 $(291.3 \pm 1.98 \mathrm{~g}), \mathrm{T} 2$ $(282.4 \pm 0.92 \mathrm{~g})$ and T1 $(260.05 \pm 5.72 \mathrm{~g})$. The highest specific growth rate (SGR) was seen in treatment T4 (1.77 \pm 0.04$)$ which was not significantly different with $\mathrm{T} 3(1.71 \pm 0.016)$ but was significantly different with $\mathrm{T} 2(1.65 \pm 0.034)$ and $\mathrm{T} 1$ $(1.52 \pm 0.037)$. The lowest food conversion ratio (FCR) was seen in T4 $(2.38 \pm 0.07)$ which was not significantly different with $\mathrm{T} 3(2.56 \pm 0.03)$ but was significantly different than $\mathrm{T} 2(2.72 \pm 0.08)$ and $\mathrm{T} 1(2.99 \pm 0.02)$. Similarly, the highest protein efficiency ratio (PER) was seen in treatment T4 $(0.94 \pm 0.05)$ which was not significantly different with T3 $(0.87 \pm$ $0.018)$ but was significantly different than $T 2(0.82 \pm 0.04)$ and $T 1(0.74 \pm 0.007)$. After $90^{\text {th }}$ days of culture period the cortisol level $(\mathrm{mg} / \mathrm{ml})$ were lower in the group fed with $3 \%$ of the plant additives. The treatment $\mathrm{T} 4(0.17 \pm 0.01) \mathrm{had}$ significantly lower level of cortisol with T3 $(0.295 \pm 0.04)$, T2 $(0.38 \pm 0.04)$ and T1 $(0.935 \pm 0.04)$. The red blood cell $(\mathrm{RBC})$ counts $\left(10^{6}\right.$ cells $\left./ \mathrm{ml}\right)$ in T4 $(1.94 \pm 0.2)$ was significantly higher than T3 $(1.51 \pm 0.1)$, T2 $(1.1 \pm 0.1)$ and T1 $(1.02 \pm 0.3)$. Similarly, white blood cell (WBC) count $\left(10^{3}\right.$ cells $\left./ \mathrm{ml}\right)$ was also significantly higher in $\mathrm{T} 4(12.55 \pm 0.2)$ than $\mathrm{T} 3(12.11 \pm$ $0.2), \mathrm{T} 2(11.54 \pm 0.1)$ and $\mathrm{T} 1(10.71 \pm 0.3)$. No significant changes were observed in water temperature $\left({ }^{\circ} \mathrm{C}\right)$, dissolved oxygen $(\mathrm{mg} / \mathrm{l})$ and $\mathrm{pH}$ under different treatments. The present findings demonstrated that dietary inclusion of stinging nettle enhanced growth, lower cortisol level and increase RBC and WBC count of the fish; thus stimulating the immunity and lower the stress level.
\end{abstract}

Key words : Urtica parviflora, Total harvest weight, FCR, SGR, PER, Cortisol, RBC, WBC.

\section{INTRODUCTION}

Aquaculture has become the fastest growing and it is expected to be the biggest source of food by the year 2030 among the all food sector in the world (Brugere \& Ridler, 2004; Carella \& Sirri,2017 and FAO,2018). Nepalese cold water streams offer excellent habitat to at least 76 native cold water fish species(Rajbanshi,2002). Rainbow trout, a salmonid species has an economic importance worldwide with global production of 814,090 tons in 2016 (FAO,2018) and contributes to the indigenous food security with annual production of 300 tons in 2016 thus establishing itself as one of the main cultured fish species in Nepal (FAEPD,2012; Kalbassi et al., 2013 and FRD,2017). Intensive farming of rainbow trout in flow-through systems is common practice in cold water aquaculture of Nepal. With the surge in demand of rainbow trout, there is a rapid shift in aquaculture system from extensive to intensive thus pose more risk of diseases (Dawood \& Koshio,2016a,b and Yan et al.,2017) which act as major limiting factors for aquaculture development (Wunderlich et al., 2017).

Antibiotics and vaccination are the major controlling agents used for the diseases but are restricted on the behalf of their negative effects on inhibiting the immune system and other environmental troubles (Dawood et al.,2017; Chi et al., 2016 and Das et al.,2016). For strengthening the immune system and minimizing the extreme economic losses in the aquaculture industry, a new approach is being applied that includes the diligent use of dietary natural additives and feed supplements. Many of the medicinal herbs, probiotics, prebiotics and symbiotics as functional feed additives have been appraised for their desired effects on the immune system, growth function and disease resistivity (Adel et al., 2016; Van Doan et al.,2017; Ringo \& Song,2016 and Yarahmadi et al.,2016).

Urtica parviflora Roxb. commonly known as stinging nettle is a monoecious, perennial plant belonging to the Urticaceae family. It is a long stolon producing rhizomes, mainly found in forests and tall herbaceous vegetation, between elevations of $1700 \mathrm{~m}$ and $2800 \mathrm{~m}$ above sea level; in moist and partly shaded places in Bhutan, Nepal, Western China \& India (Kumar et al.,2014,2017)The itching and burning sentience is mainly due to the comportment of histamine and 5-hydroxytryptamine. Acetylcholine, malic acid, aspartic acid, serine, tyrosine and tryptophan are also found in accession.

Cost-effectiveness, sufficient availability and easy processing are some emerging characteristic of this herb that makes it as an excellent, cheap and widely accepted dietary ac- 
cessory on the intensive farming (Vico et al.,2018). But still, it is considlered as an undervalued and often disregarded plant regardless of great possibility as a useful crop under inferior input cultivation. Furthermore, there is very less literature regarding the use of stinging nettle in aquaculture limiting the applied study of its application in aquaculture. Therefore, the present study was conducted, to evaluate the effect of stinging nettle on growth, immunity and stress level of the rainbow trout fry and to optimize the inclusion rate of the stinging nettle in trout feed.

\section{MATERIAL AND METHODS}

Experimental site and design : The experiment was carried out under controlled hatchery conditions at Rainbow Trout Fishery Research Station, Dhunche $\left(28.1080^{\circ} \mathrm{N}, 85.2891^{\circ} \mathrm{E}\right)$ located at the altitude of 1850 meter above sea level. Initially, about 2500 larvae of 1-2 g size were maintained in nursery raceway. During the culture period of a week, the larvae were acclimatized by feeding liver cake and control diet (commercial extruded trout feed of crude protein $34.9 \%$; crude lipid $1.17 \%$; crude fiber $4.98 \%$; total ash $16.99 \%$ ) at the rate of $10 \%$ of the body size. The larvae were nurtured for a period of a week in a flow-through raceway type. After acclimatization, 50 juveniles were netted from the nursery ponds and transferred to each individual 16 outdoor buckets with flowthrough system having surface area of $0.054 \mathrm{~m}^{3}$ for 90 days from 20 June-17 September with the stocking rate of 1,000 fish $/ \mathrm{m}^{3}$. The experiment was conducted in Completely Randomized Design (CRD) having 4 diets, diet-1:control: fish meal based, diet-2:1\% stinging nettle meal mixed of total diet, diet 3: $2 \%$ stinging nettle meal mixed with total diet and diet $4: 3 \%$ stinging nettle meal mixed with total diet. Altogether there were four treatments replicated four times. The treatments were randomized by the lottery method.

\section{Preparation of pellet diet}

Stinging nettle meal : Fresh leaves of stinging nettle were procured near Rainbow Trout Fishery Research Station, in Dhunche, Nepal. Authentication and identification of the plant was carried out at the National Herbarium and Plant Laboratories (NHPL), Godawari. The plants were cleaned and cut into small pieces, and then air dried. The dried samples were then pulverized into fine powder in a grinder, which was then stored at $4^{\circ} \mathrm{C}$ until use. The proximate analysis of stinging nettle was carried out before including in the research diet.

Four diets with same levels of dietary protein (approximately $47 \%$ ) for rainbow trout were formulated : fish meal based diet (control) and 1\%,2\% and 3\% partial replacement of fish meal with locally prepared stinging nettle meal. To prepare formulated diet for the experiment, all ingredients (Table.1) were ground thoroughly and sieved to pass through $0.05 \mathrm{~mm}$ mesh size; mixed together in a blender and then put into the electric operated pellet machine for the preparation of pellet diet of size $<0.5 \mathrm{~mm}$. The pellets were air dried and were packed in plastic bags and stored at $-4^{\circ} \mathrm{C}$.
Feeding : Fishes were hand fed with pellet feed as suggested by the Rainbow Trout daily feeding guide adapted from in accordance to the daily temperature and the total body wt. of the fishes of each bucket (Tacon,1987). The total daily feed ration was divided into five equal portions delivered at $8 \mathrm{am} ; 10 \mathrm{am}$; $12 \mathrm{pm} ; 2 \mathrm{pm}$ and $4 \mathrm{pm}$ under ambient lighting in first month and reduced to three equal portions delivered at $8 \mathrm{am} ; 12 \mathrm{pm}$ and $4 \mathrm{pm}$ in later months.

Sampling protocol : Monthly, sampling was done of each race bucket by seining. Ten fishes were randomly weighed $( \pm 0.1 \mathrm{~g})$, Phoenix instrument electronic balance Model SN014739 and its growth measurements were assessed.

Blood sampling : At the termination of the research, 5 fishes from each bucket were randomly captured with dip nets and quickly anesthetized with clove oil at $40 \mathrm{mg} / \mathrm{l}$ (Inoue et al.,2003). Blood was withdrawn from the caudal vein of each sampled fish into $1 \mathrm{ml}$ sterilized hypo-dermal syringe. Blood sample was transferred to micro tube containing heparin anticoagulant and immediately used for hematological examination (Blaxhall \& Daisley, 1973).

Determination of stress (cortisol) parameter and hematology : Plasma cortisol was analyzed using Enzymed-Linked Immunosorbent assay (ELISA) Test. Numbers of erythrocytes (red blood cells (RBC) count, $10^{6}$ cells $/ \mathrm{ml}$ ) and white blood cells (WBC) count $10^{3}$ cells $/ \mathrm{ml}$ ) were determined by the haemocytometer (Blaxhall \& Daisley,1973). All these analyses were carried out in Animal Health Research Division, Khumaltar.

Determination of growth performance : Growth of the fish was expressed as daily growth rate (DGR) and specific growth rate (SGR). Similarly, survival rate (SR), feed conversion ratio (FCR) and protein efficiency ratio (PER) were also calculated.

$\operatorname{DGR}(\mathrm{g} /$ fish/day $)=($ wf-wi $) /$ culture period

SGR $(\%$ per day $)=[(\ln (\mathrm{wf})-\ln ($ wi $) /$ culture period $] \times 100$

$\mathrm{FCR}=$ Quantity of feed supplied (kg)/ Net fish yield (kg)

$\mathrm{SR}(\%)=($ Total number of fish harvested/Total number of fish stocked) $\times 100$

$\mathrm{PER}=$ wet weight gain $(\mathrm{g}) /$ total protein intake

Where, wi and wf are the initial and final mean wet body weights in gram, respectively.

Water quality analysis : Temperature was measured at daily intervals at out flow of each raceway and dissolved oxygen (DO), $\mathrm{pH}$ was measured fortnightly. Portable $\mathrm{pH}$ meter by Thermos-Electron Corporation Russell 060p was used to monitor $\mathrm{pH}$ and Temperature was measured using digital thermometer. Similarly, Orion 5 star S. N. 005840 by ThermoElectron Corporation, USA, was used to monitor dissolved oxygen. Temperature in degree centigrade $\left({ }^{\circ} \mathrm{C}\right)$ and dissolved oxygen in parts per million ( $\mathrm{mg} / \mathrm{l})$ was noted for each value monitored. 
Table. 1 Ingredients and composition, percent of the experimental diet.

\begin{tabular}{lcccc}
\hline Ingredient & \multicolumn{4}{c}{ Treatments } \\
\cline { 2 - 5 } & T1 (Control) & T2 & T3 & T4 \\
\hline Jwala (Small Shrimp) & 51.86 & 51.67 & 51.46 & 51.31 \\
Soya full roasted & 35 & 35 & 35 & 35 \\
Wheat grain & 13.69 & 12.33 & 11.54 & 10.69 \\
& Additional & & & \\
Vitamin premix* & 2 & 2 & 2 & 2 \\
Mineral mix** & 2 & 2 & 2 & 2 \\
Liver tonic & 3 & 3 & 3 & 3 \\
Yeast & 1 & 1 & 1 & 1 \\
Salt & 1 & 1 & 1 & 1 \\
Additives & & & & \\
Stinging nettle & 0 & 1 & 2 & 3 \\
\hline
\end{tabular}

*Vitamin mixture/kg premix containing the following : 33000 IU vitamin A, 3300 IU, vitamin D3, 410 IU vitamin E, $2660 \mathrm{mg}$ Vitamin BI, $133 \mathrm{mg}$ vitamin B2, $580 \mathrm{mg}$ vitamin B6, $41 \mathrm{mg}$ vitamin B12, $50 \mathrm{mg}$ biotin, $9330 \mathrm{mg}$ choline chloride, $4000 \mathrm{mg}$ vitamin C, $2660 \mathrm{mg}$ Inositol, $330 \mathrm{mg}$ para-amino benzoic acid, $9330 \mathrm{mg}$ niacin, $26.60 \mathrm{mg}$ pantothenic acid. ${ }^{* *}$ Mineral mixture/kg premix containing the following : $325 \mathrm{mg}$ Manganese, $200 \mathrm{mg}$ Iron, $25 \mathrm{mg}$ Copper, $5 \mathrm{mg}$, Iodine, $5 \mathrm{mg}$ Cobalt.

Harvesting : Final harvesting of rainbow trout was done after 90 days by draining each bucket completely on termination of the research. Harvested fish was measured using electronic balance. Fish was counted and their batch weight was recorded.

Statistical analysis : The data were collected during the course of time and on the basis of individual fish observations, the population means for each parameter was computed. The mean and standard errors were calculated for each treatment. The analysis of variance was used to compare different growth parameters, stress parameter and hematological parameters using R-St at version 3.3.2. The data entry was done through MS Excel 2016. The accepted level of significance was $\mathrm{p}<0.05$

\section{RESULTS AND DISCUSSION}

Growth parameters : The total stock weight, total stock number, mean stock weight, total harvest weight, total harvest number, mean harvest weight and survivability of fish in different treatments are presented in Table.2. Similarly daily growth rate (DGR) and specific growth rate (SGR) in different treatments during experimental period are presented in Table.2.

A mean weight of about $1.4 \mathrm{~g}$ size fry were stocked at the beginning of experiment in all treatments which were not significantly different with each other $(\mathrm{p}>0.05)$. The stocking number of fish fry was 50 per bucket. Result showed that there was no significant difference in harvest number and survival of fishes among the treatments. At the end of the experiment total harvest weight of fish in T4 $(315.95 \pm 8.11 \mathrm{~g})$ was significantly higher than T3 $(291.3 \pm 1.98 \mathrm{~g})$, T2 $(282.4 \pm 0.92 \mathrm{~g})$ and $\mathrm{T} 1(260.05 \pm 5.72 \mathrm{~g})$ and significantly different at $(\mathrm{p}<0.05)$. Likewise, T2 and T3 were also significantly different than T1 $(p<0.05)$ but were not different with each other $(p>0.05)$.
Significant differences in FCR and protein efficiency ratio (PER) were observed among treatments during the study period $(\mathrm{p}<0.05)$. The lowest FCR was seen in T4 $(2.38 \pm 0.07)$ which was not significantly different with T3 $(2.56 \pm 0.03)$ ( $p>0.05$ ) but was significantly different than T1 $(2.72 \pm 0.08)$ and T2 $(2.99 \pm 0.02)(\mathrm{p}<0.05)$. However, T3 was also not significantly different with T2 $(\mathrm{p}>0.05)$ but both were significantly different with $\mathrm{T} 1(\mathrm{p}<0.05)$. Similarly, the highest PER was seen in T4 $(0.94 \pm 0.05)$ which was not significantly different with $\mathrm{T} 3(0.87 \pm 0.018)(\mathrm{p}>0.05)$ but was significantly different than T2 $(0.82 \pm 0.04)$ and T1 $(0.74 \pm 0.007)(p<0.05)$. However, T3 was also not significantly different with T2 $(p>0.05)$ but was significantly different with T1 $(p<0.05)$ whereas $\mathrm{T} 2$ was not significantly different with $\mathrm{T} 1(\mathrm{p}>0.05)$.

In a like manner, there was a significant difference $(p<0.05)$ in specific growth rate but not in mean thermal unit growth coefficient, daily growth coefficient, daily growth rate observed among treatments $(\mathrm{p}>0.05)$ over time. The DGR was highest in T4 $(0.06 \pm 0.001 \mathrm{~g}$ /day $)$ but not significantly different with T3 $(0.05 \pm 0.001 \mathrm{~g} /$ day $), \mathrm{T} 2(0.05 \pm 0.002 \mathrm{~g} /$ day $)$ and $\mathrm{T} 1(0.05 \pm 0.004 \mathrm{~g} /$ day $)(\mathrm{p}>0.05)$

Nonetheless, the highest SGR was seen in treatment T4 (1.77 \pm 0.04$)$ which was not significantly different with T3 $(1.71 \pm 0.016)(\mathrm{p}>0.05)$ but was significantly different with $\mathrm{T} 2$ $(1.65 \pm 0.034)$ and T1 $(1.52 \pm 0.037)(\mathrm{p}<0.05)$. T3 was statistically at par with T2 $(\mathrm{p}>0.05)$ but both were significantly different with $\mathrm{T} 1$ at $\mathrm{p}<0.05$. The monthly growth trend of rainbow trout fry during the experimental period is illustrated in Fig.1. The fries grew steadily until 60 days of culture and exponentially from then after up to 90 days.

Blood parameters : The cortisol level, RBC count and WBC count of fish in different treatments are presented in Table. 3 After 90 days of culture period the cortisol level were significantly lower and different in the group fed with $\mathrm{T} 4(\mathrm{p}<0.05)$. The T4 $(0.17 \pm 0.01 \mathrm{mg} / \mathrm{ml})$ had significantly lower and different level of cortisol as compare toT3 $(0.29517 \pm 0.04 \mathrm{mg} / \mathrm{ml})$, $\mathrm{T} 2(0.3817 \pm 0.04 \mathrm{mg} / \mathrm{ml})$ and $\mathrm{T} 1(0.93517 \pm 0.04 \mathrm{mg} / \mathrm{ml})$ $(\mathrm{p}<0.05)$. Likewise, after 90 days of culture, red blood cell (RBC) and white blood cells (WBC) counts were enhanced in T4. The RBC counts in T4 $\left(1.94 \times 10^{6} \pm 0.2 / \mathrm{ml}\right)$ was significantly higher and different with each other with $\mathrm{T} 3\left(1.51 \mathrm{x} 10^{6}\right.$ $\pm 0.1 / \mathrm{ml})$, T2 $\left(1.1 \times 10^{6} \pm 0.1 / \mathrm{ml}\right)$ and $\mathrm{T} 1\left(1.02 \times 10^{6} \pm 0.3 / \mathrm{ml}\right)$ However, T2 was not significantly different with T1 in RBC counts $(p>0.05)$. Similarly, WBC counts were significantly different with each other. The highest WBC count was observed in T4 $\left(12.55 \times 10^{3} \pm 0.09 / \mathrm{ml}\right)$ which was significantly different with T3 $\left(12.11 \times 10^{3} \pm 0.05 / \mathrm{ml}\right), \mathrm{T} 2\left(11.54 \times 10^{3} \pm 0.13 / \mathrm{ml}\right)$ and $\mathrm{T} 1\left(10.71 \times 10^{3} \pm 0.08 / \mathrm{ml}\right)$ at $\mathrm{p}<0.05$.

Water quality : Mean and range of temperature was measured daily whereas $\mathrm{pH}$ and dissolved oxygen of water was measured fortnightly during experimental period which are represented in the Table.4. Water quality during the experimental period was found at desired level. Parameters like temperature, $\mathrm{pH}$ and dissolved oxygen were not significantly different $(\mathrm{p}>0.05)$ among treatments. 
Growth parameters : Results showed that the mean harvest weight were significantly different with each other. The highest mean harvest weight was seen in T4 $(6.91 \pm 0.03 \mathrm{~g})$ followed by T3 $(6.34 \pm 0.01 \mathrm{~g}), \mathrm{T} 1(5.81 \pm 0.04 \mathrm{~g})$. Result showed that the total harvest weight ranged from $260.1-315.9 \mathrm{~g} / 0.054$ $\mathrm{m}^{3}$ bucket among the treatments during the rearing period of $90^{\text {th }}$ days. The total harvest weight of T4 was found to be highest than other treatments (T1, T2 \& T3) and were significantly different $(p<0.05)$; but T2 \& T3 were not significantly different among each other $(p>0.05)$. Similarly, there was significant difference in SGR among dietary included group (T2, T3 $\& \mathrm{~T} 4)$ and the control one, $\mathrm{T} 1(\mathrm{p}<0.05)$ but there was no significant difference between the SGR of feeds included with stinging nettle $(p>0.05)$. In a similar manner, FCR of the control group (T1) was significantly higher than the dietary included ones $(\mathrm{T} 2, \mathrm{~T} 3 \& \mathrm{~T} 4)(\mathrm{p}<0.05)$.

Results findings suggest that there was enhancement in total harvest weight, SGR and FCR with dietary inclusion of $3 \%$ of stinging nettle compared to control groups. Affirmative result were seen in the total weight gain, FCR and SGR of Victoria Labeo (Labeo victorianus) fed with similar herbal additive (Ngugi et al.,2015). Similar research findings were also been observed by Adel et al. (2017) who concluded that total weight gain, SGR and FCR was elevated in 3\% level of dietary inclusion of stinging nettle. With the increase in dietary inclusion of stinging nettle there is significant increase in weight gain, FCR and SGR in rainbow trout as seen in the work of Bilen et al. (2016). The PER of the treatment T4 (0.94 $\pm 0.05)$ was higher and significantly different than T2 and T1 $(p<0.05)$ but was not significantly different than $\mathrm{T} 3(\mathrm{p}>0.05)$. With the significant decrease in FCR, there was increment in PER with the increment in the dietary inclusion of stinging nettle in rainbow trout juveniles as seen in work of Bilen et al. (2016). A significant increase in PER, SGR and final weight was seen in Nile tilapia fed with fenugreek seeds with similar result was found in rainbow trout fed with garlic (Abdelhamid \& Soliman,2012). Likewise, elevated weight gain was also found in garlic fed Nile tilapia (Nya \& Austin, 2009 and Shalaby et al.,2006). Restricted growth and settlement of many pathogenic and non-pathogenic group of bacteria in fish gut due to the herbal add on sums up for the more efficient use of diet, resulting in improved growth and greater feed efficiency (Dawood et al.,2014). Enhancement in the feed palatability due to the betterment in feed utilization as demon- strated by the FCR results increase in feed consumption and growth rate of fish. The monthly growth trend of rainbow trout fry shows that fry grew steadily until 60 days of culture and exponentially from then after up to 90 days. Similar result was observed by Wagner et al. (1996) in rainbow trout fry and Pandit and Nakamura (2010) in Nile tilapia fry. No significant changes were observed in water temperature $\left({ }^{\circ} \mathrm{C}\right)$, dissolved oxygen (mg/l) and $\mathrm{pH}$ under different treatments $(\mathrm{p}>0.05)$.

Stress (cortisol) and blood parameters : Due to cortisol being the most readily stress hormone to assess the activity of hypothalamic-pituitaryinterrenal axis - HPI- (Donaldson,1981), the increase of plasma levels has been frequently associated to short-term stressors (Bayunova et al.,2002). Several factors affect the plasma cortisol levels in fish including size and age of fish, time of day, rearing temperature (Barry et al.,1993; Cataldi et al.,1998 and Lankford et al.,2003), reproductive stage (Schreck et al.,2001), acclimation conditions, handling (Carey and McCormick,1998; Bayunova et al.,2002), tank confinement (Barry et al.,1993 and Bayunova et al.,2002), use of anaesthetics, changes of osmotic condition (Kelly and Woo,1999), air exposition (Carey and McCormick,1998 and Bayunova et al.,2002) and fish strains. Variation of response to stressful condition among species has been reported, being salmonids one of the species that respond almost immediately to handling and crowding stress (Carey \& McCormick, 1998). In the present study, the higher values of plasma cortisol observed could be associated with these later conditions, especially with the handling stress during sampling and harvesting.

The evaluation of biochemical characteristics in fish is important in understanding the normal, pathological processes and toxicological impacts (Sudova et al.,2009). Biochemical profiles of an organism may provide important information about the internal environment of the organism. Our results revealed significant influence of dietary inclusion of stinging nettle on the biochemical parameters of juvenile Oncorhynchus mykiss. In the current study, plasma cortisol decreased with increasing Urtica parviflora which was similar to the Urtica dioica fed diet of juveniles and adults fish of Labeo victorianus (Ngugi et al.,2015), which differ from those reported in Labeo rohita fed diets supplemented with Ocimum sanctum extracts (Das et al.,2015). Any form of disturbance in fish culture units usually result in production of

Table. 2 Mean value of growth parameters of rainbow trout during experimental period of 90 days. All data presented are for $0.054 \mathrm{~m}^{3}$ bucket size.

\begin{tabular}{|c|c|c|c|c|}
\hline \multirow[t]{2}{*}{ Growth parameters } & \multicolumn{4}{|c|}{ Treatments (Mean \pm SE) } \\
\hline & T1 (Control) & $\mathbf{T 2}$ & T3 & T4 \\
\hline Total stock weight (g) & $65.9 \pm 1.17$ & $63.6 \pm 2.08$ & $62.2 \pm 0.79$ & $64.2 \pm 1.15$ \\
\hline Total harvest weight (g) & $260.1 \pm 5.72^{\mathrm{c}}$ & $282.4 \pm 0.92^{\mathrm{b}}$ & $291.3 \pm 1.98^{\mathrm{b}}$ & $315.9 \pm 8.11^{\mathrm{a}}$ \\
\hline Survival (Percent) & $89.5 \pm 1.5$ & $92 \pm 1.41$ & $92 \pm 1.41$ & $91.5 \pm 2.06$ \\
\hline Daily growth rate (DGR) & $0.05 \pm 0.004$ & $0.05 \pm 0.002$ & $0.05 \pm 0.001$ & $0.06 \pm 0.001$ \\
\hline Specific growth rate (SGR) & $1.52 \pm 0.037^{\mathrm{c}}$ & $1.65 \pm 0.034^{\mathrm{b}}$ & $1.71 \pm 0.016^{\mathrm{ab}}$ & $1.77 \pm 0.04^{\mathrm{a}}$ \\
\hline Food conversion ratio (FCR) & $2.99 \pm 0.02^{\mathrm{a}}$ & $2.72 \pm 0.08^{\mathrm{ab}}$ & $2.56 \pm 0.03^{\mathrm{bc}}$ & $2.38 \pm 0.07^{\mathrm{c}}$ \\
\hline Protein efficiency ratio (PER) & $0.74 \pm 0.007^{\mathrm{c}}$ & $0.82 \pm 0.04^{\mathrm{bc}}$ & $0.87 \pm 0.018^{\mathrm{ab}}$ & $0.94 \pm 0.05^{\mathrm{a}}$ \\
\hline
\end{tabular}
$\mathrm{T} 1=$ Control Diet $1 ; \mathrm{T}=1 \%$ stinging nettle Diet $2 ; \mathrm{T} 3=2 \%$ stinging nettle $\mathrm{D}$.
different superscript letter within same row are significantly different at $\mathrm{p}<0.05$. 
high cortisol due to mobilization of energy for osmoregulatory purposes (Barton et al.,2000), in this case which was due to handling stress.

Culture circumstances, immunological conditions and primary diet make up can alter the haematological parameters which are the dependable indicators of general health situation of fish (Eslamloo et al.,2012). In the current study, there is significant improvement of haematological parameters on 90 days feeding with Urtica parviflora. Juvenile Huso huso fed with diets supplemented with Urtica diocia (Binaii et al., 2014); Morus alba extract fed Clarias gariepinus (Sheikhlar et al.,2014) and Cyprinus carpio fed with Euphorbia hirta (Pratheepa and Sukumaran,2014) and Aegle marmelos (Pratheepa et al., 2010) had similar results and in agreement with the result of increased in $\mathrm{RBC}$ in the current study. The result of Nya and Austin is also corresponding towards the current study which account for the increased in the RBC count with rainbow trout fed with garlic and ginger based diets (Nya \& Austin, 2009). Due to availability of the iron, vitamin A, vita$\min \mathrm{B}$, vitamin C and vitamin B12 in Urtica parviflora there is significant increase in the RBC count as seen in dietary supplements of Urtica dioica which are apparently needed for the RBC production (Dugenci et al.,2003; Gulcin et al.,2004; Manganelli et al., 2005 and Lim et al.,2000). The similar studies of Dugenci et al. (2003), Awad \& Austin (2010), Jian \& Wu (2003,2004), Sahu et al. (2007); Harikrishnan et al. (2010) has shown a significant increase in WBC as in the current study with the inclusion of Urtica parviflora in diets of rainbow trout. Aeromonas hydrophila challenged fish fed with dietary Urtica dioica also showed significant increase in the white blood cell which were also similar to the work of Nya and Austin (Ngugi et al.,2015 and Nya \& Austin,2009) and neem added diet fed to the broiler chicken (Obikaonu et al.,2012). The increment in the RBC and WBC counts indicate the immunological and anti-infective effects of the plants.

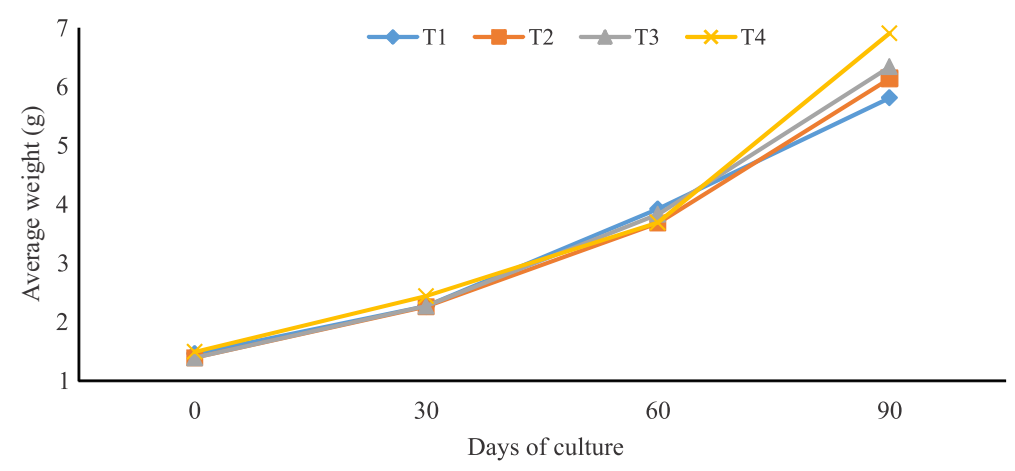

Fig. 1 Growth trends of rainbow trout fry in different treatments during experimental period of 90 days. $\mathrm{T} 1=$ Control Diet 1; T2 = 1\% stinging nettle Diet 2; T3 = 2\% stinging nettle Diet 3 and T4 = 3\% stinging nettle Diet 4 .

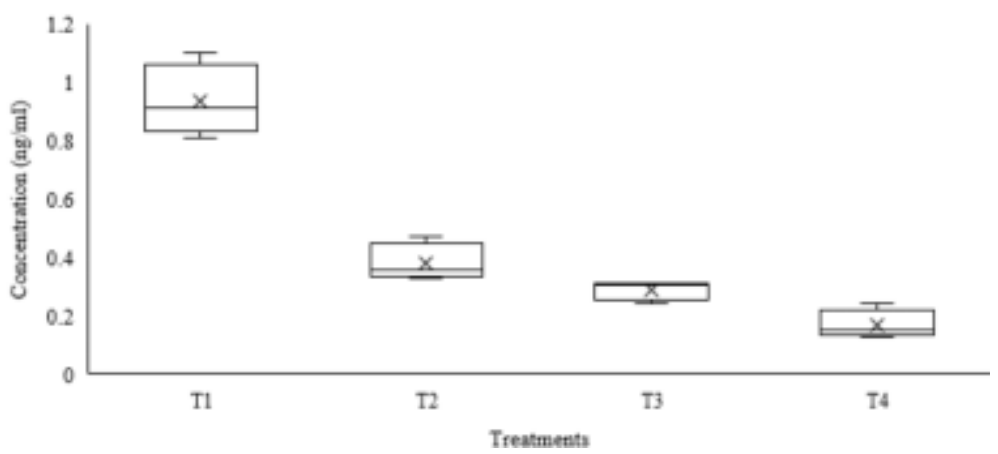

Fig. 2 Box-Whisker plot of cortisol concentration $(\mathrm{mg} / \mathrm{ml})$ of different treatments at the end of the experiment of 90 days. T1 $=$ Control Diet 1; T2 = 1\% stinging nettle Diet 2; T3 = 2\% stinging nettle Diet 3 and T4 = 3\% stinging nettle Diet 4 .

Table. 3 Cortisol levels, RBC and WBC parameters of rainbow trout fed with different level of dietary U.parviflora 90 days.

\begin{tabular}{|c|c|c|c|}
\hline Constituents & RBC count $\left(10^{6} / \mathrm{ml}\right)($ Mean \pm SE $)$ & WBC count $\left(10^{3} / \mathrm{ml}\right)($ Mean \pm SE $)$ & Cortisol $(\mathrm{mg} / \mathrm{ml})($ Mean \pm SE $)$ \\
\hline T1 (Control) & $1.02 \pm 0.01^{\mathrm{c}}$ & $10.71 \pm 0.08^{\mathrm{d}}$ & $0.934 \pm 0.03^{\mathrm{c}}$ \\
\hline $\mathrm{T} 2$ & $1.10 \pm 0.03^{\mathrm{c}}$ & $11.54 \pm 0.13^{\mathrm{c}}$ & $0.380 \pm 0.04^{\mathrm{b}}$ \\
\hline T3 & $1.51 \pm 0.0 .04^{\mathrm{b}}$ & $12.11 \pm 0.05^{\mathrm{b}}$ & $0.295 \pm 0.04^{\mathrm{b}}$ \\
\hline $\mathrm{T} 4$ & $1.94 \pm 0.0 .08^{\mathrm{a}}$ & $12.55 \pm 0.09^{\mathrm{a}}$ & $0.170 \pm 0.01^{\mathrm{a}}$ \\
\hline
\end{tabular}
letter within same row are significantly different at $\mathrm{p}<0.05$. 
Table. 4 Values of water quality parameters temperature $\left({ }^{\circ} \mathrm{C}\right)$ measured daily and dissolved oxygen $(\mathrm{mg} / \mathrm{l})$ and pH measured fortnightly during experimental period of 90 days.

\begin{tabular}{lcccc}
\hline Water quality parameters & \multicolumn{4}{c}{ Treatments (Mean \pm SE) } \\
\cline { 2 - 5 } & \multicolumn{1}{c}{ T1 } & T2 & T3 & T4 \\
\hline Temperature $\left({ }^{\circ} \mathrm{C}\right)$ & $17.6 \pm 0.049(17-18.4)$ & $17.6 \pm 0.049(17-18.4)$ & $17.6 \pm 0.049(17-18.4)$ & $17.6 \pm 0.049(17-18.4)$ \\
Dissolved oxygen $(\mathrm{mg} / \mathrm{l})$ & $8.63 \pm 0.09(8.48-8.87)$ & $8.47 \pm 0.07(8.3-8.64)$ & $8.64 \pm 0.1(8.37-8.83)$ & $8.46 \pm 0.19(8.01-8.95)$ \\
$\mathrm{pH}$ & $8.5 \pm 0.05(8.4-8.66)$ & $8.3 \pm 0.09(8.11-8.45)$ & $8.4 \pm 0.07(8.2-8.53)$ & $8.4 \pm 0.07(8.19-8.53)$ \\
\hline
\end{tabular}

Mean value with different superscript letter within same row are significantly different at $\mathrm{p}<0.05$.

The increasing public concern about antibiotic resistance and their effect on environment has brought about increased scrutiny on the use of antibiotics in aquaculture. Many approaches have been deployed for replacing antibiotics used primarily through immunostimulants. Supplementation of immunostimulants in feed can improve the fish health and thereby reduce management costs.

The present study was conducted to evaluate the dietary inclusion rate of stinging nettle (Urtica parviflora) on growth, immune stress responses of rainbow trout fry. Therapeutic potential of the stinging nettle as dietary supple- ment would improve growth, lower cortisol (stress factor) level and elevate RBC \& WBC count as evident in this study.

Inclusion of $3 \%$ stinging nettle on basal diet shows higher growth rate, better hematological responses with lower stress than rest of the treatments. Likewise, $1 \%$ and $2 \%$ inclusion of stinging nettle on basal diet also shows better performance than that of the control. The findings of the present study provided new insight into immuno-stimulatory and stress modulating capacity of the stinging nettle incorporated in trout and possibly contribute to an enhancement in trout welfare.

\section{REFERENCES}

Abdelhamid, A. M. and Soliman, A. A. A. (2012). Possibility of using fenugreek seeds or cresson seeds in Tilapia diets. Journal of Arabian Aquaculture Society, $7:$ 75-90.

Adel, M.; Pourgholam, R.; Zorriehzahra, J. and Ghiasi, M. (2016). Hemato-Immunological and biochemical parameters, skin antibacterial activity, and survival in rainbow trout (Oncorhynchus mykiss) following the diet supplemented with Mentha piperita against Yersinia ruckeri. Fish and Shellfish Immunology, $55: 267-273$.

Adel, M.; Caipang, C. M. A. and Dawood, M. A. (2017). Immunological responses and disease resistance of rainbow trout (Oncorhynchus mykiss) juveniles following dietary administration of stinging nettle (Urtica dioica). Fish and Shellfish Immunology, 71:230-238.

Awad, E. and Austin, B. (2010). Use of lupin, Lupinus perennis, mango, Mangifera indica and stinging nettle, Urtica dioica, as feed additives to prevent Aeromonas hydrophila infection in rainbow trout, Oncorhynchus mykiss (Walbaum). Journal of Fish Diseases, 33 : 413-420.

Barry, T. P.; Lapp, A. F.; Kayes, T. B. and Malison, J. A. (1993). Validation of a microtitre plate ELISA for measuring cortisol in fish and comparison of stress responses of rainbow trout (O.mykiss) and lake trout (Salvelinus namaycush). Aquaculture, 117(3-4):351-363.

Barton, D. R.; Kelton, N. and Eedy, R. I. (2000). The effects of carp (Cyprinus carpio L.) on sediment export from a small urban impoundment. Journal of Aquatic Ecosystem Stress and Recovery, 8(2):155-159.

Bayunova, L.; Barannikova, I. and Semenkova, T. (2002). Sturgeon stress reactions in aquaculture. Journal of Applied Ichthyology, 18(4-6) : 397-404.

Bilen, S.; Unal, S. and Guvensoy, H. (2016). Effects of oyster mushroom (Pleurotus ostreatus) and nettle (Urtica dioica) methanolic extracts on immune responses and resistance to Aeromonas hydrophila in rainbow trout (Oncorhynchus mykiss). Aquaculture, 454:90-94.

Binaii, M.; Ghiasi, M.; Farabi, S. M. V.; Pourgholam, R.; Fazli, H.; Safari, R.; Bankehsaz, Z. (2014). Biochemical and hemato-immunological parameters in juvenile beluga (Huso huso) following the diet supplemented with nettle (Urtica dioica). Fish and Shellfish Immunology, 36(1): 46-51

Blaxhall, P. C. and Daisley, K. W. (1973). Routine haematological methods for use with fish blood. Journal of Fish Biology, 5(6) : 771-781.

Brugère, C. and Ridler, N. (2004). Global Aquaculture outlook in the next decades : An analysis of National Aquaculture Production Forecasts to 2030. FAO Fisheries Circular No. 1001. Rome, pp. 1-47.

Carella, F. and Sirri, R. (2017). Editorial : Fish and shellfish pathology. Frontier in Marine Science, $4: 375$.

Carey, J. B. and McCormick, S. D. (1998). Atlantic salmon smolts are more responsive to an acute handling and confinement stress than parr. Aquaculture, 168(1-4) : 237-253.

Cataldi, E.; Di Marco, P.; Mandich, A. and Cataudella, S. (1998). Serum parameters of Adriatic sturgeon Acipenser naccarii (Pisces : Acipenseriformes) : Effects of temperature and stress. Comparative Biochemistry and Physiology Part A: Molecular \& Integrative Physiology, 121(4) : 351-354 
Chi, C.; Giri, S. S.; Jun, J. W.; Kim, H. J.; Yun, S.; Kim, S. G. and Park, S. C. (2016). Immunomodulatory effects of a bioactive compound isolated from Dryopteris crassirhizoma on the grass carp Ctenopharyngodon idella. Journal of Immunology Research, p. 2.

Das, K. K.; Abedin, A. and Noor, R. (2016). Anti-bacterial activity of natural plants on fish pathogens isolated from different ponds of Dhaka city. Bangladesh Journal of Microbiology, 31(1) : 9-12.

Das, R.; Raman, R. P.; Saha, H. and Singh, R. (2015). Effect of Ocimum sanctum Linn. (Tulsi) extract on the immunity and survival of Labeo rohita (Hamilton) infected with Aeromonas hydrophila. Aquaculture Research, 46(5) : 1111-1121.

Dawood, M. A.; El-Dakar, A.; Mohsen, M.; Abdelraouf, E.; Koshio, S.; Ishikawa, M. and Yokoyama, S. (2014). Effects of using exogenous digestive enzymes or natural enhancer mixture on growth, feed utilization, and body composition of rabbitfish, Siganus rivulatus. Journal of Agriculture Science and Technology, Iran, $4: 180-187$

Dawood, M. A. O. and Koshio, S. (2016a). Recent advances in the role of probiotics and prebiotics in carp aquaculture : A review. Aquaculture, $454: 243-251$.

Dawood, M. A. O. and Koshio, S. (2016b). Vitamin C supplementation to optimize growth, health and stress resistance in aquatic animals. Reviews in Aquaculture, 10(2) : 334-350.

Dawood, M. A. O.; Koshio, S. and Esteban, M. A. (2017). Beneficial roles of feed additives as immunostimulants in aquaculture : A review. Reviews in Aquaculture, 10(4) : 950-974.

Donaldson, E. M. (1981). Pituitary-interrenal axis as an indicator of stress in fish. Stress and Fish, pp. 11-47.

Dügenci, S. K.; Arda, N. and Candan, A. (2003). Some medicinal plants as immunostimulant for fish. Journal of Ethnopharmacology, 88(1) : 99-106.

Eslamloo, K.; Falahatkar, B. and Yokoyama, S. (2012). Effects of dietary bovine lactoferrin on growth, physiological performance, iron metabolism and non-specific immune responses of Siberian sturgeon Acipenser baeri. Fish and Shellfish Immunology, 32(6) : $976-985$.

FAO (2018). The state of world fisheries and aquaculture, meeting the sustainable development goals. Food and Agriculture Organization of the United Nations, pp. 23.

FAEPD (2012). The State of World Fisheries and Aquaculture - 2012. Fishery and Aquaculture Economics and Policy Division Rome, FAO.

FRD (2017). Annual Report 2071/72 (2014/15). Fisheries Research Division NARC, Godawari, Lalitpur, Nepal, p. 12.

Gülçin, I.; Kufreviolu, O.; Oktay, M. and Buyukokurolu, M. E. (2004). Antioxidant, antimicrobial, antiulcer and analgesic activities of nettle (Urtica dioica L.). Journal of Ethnopharmacology, 90(2-3) : 205-215.

Harikrishnan, R.; Balasundaram, C. and Heo, M. S. (2010). Herbal supplementation diets on hematology and innate immunity in goldfish against Aeromonas hydrophila. Fish \& Shellfish Immunology, 28(2) : 354-361.

Inoue, L. A. K. A.; Santos Neto, C. dos and Moraes, G. (2003). Clove oil as anaesthetic for juveniles of matrinxa Brycon cephalus (Gunther, 1869). Ciencia Rural, 33(5) : 943-947.

Kalbassi, M. R.; Abdollahzadeh, E. and Salari-Joo, H. (2013). A review on aquaculture development in Iran. Ecopersia, 1(2): $159-178$.

Kelly, S. P. and Woo, N. Y. S. (1999). The response of sea bream following abrupt hyposmotic exposure. Journal of Fish Biology, 55(4) : 732750 .

Kumar, S.; Ahmad, S. and Harikumar, S. L. (2014). Pharmacognostical and pharmacological studies of Urtica parviflora Roxb. : A review. International Journal of Universal Pharmacy and Bio-sciences, 3(4) : 179-184.

Kumar, A.; Bisht, A. S.; Joshi, S. and Juyal, D. (2017). Pharmacognostical and phytochemical study of a plant Urtica parviflora Roxb. : A review. Journal of Pharmacognosy and Phytochemistry, 6(3): 42-45.

Lankford, S. E.; Adams, T. E. and Cech, J. J. (2003). Time of day and water temperature modify the physiological stress response in green sturgeon, Acipenser medirostris. Comparative Biochemistry \& Physiology. Part A, Molecular \& Integrative Physiology, 135(2): $291-302$.

Lim, C.; Klesius, P. H.; Li, M. H. and Robinson, E. (2000). Interaction between dietary levels of iron and vitamin C on growth, hematology, immune response and resistance of channel catfish (Ictalurus punctatus) to Edwardsiella ictaluri challenge, Aquaculture, 185:313-327.

Manganelli, R. E. U.; Zaccaro, L. and Tomei, P. (2005). Antiviral activity in vitro of Urtica dioica L., Parietaria diffusa and Sambucus nigra L. Journal of Ethnopharmacology, $98: 323-327$.

Ngugi, C. C; Oyoo-Okoth, E.; Mugo-Bundi, J.; Orina, P. S.; Chemoiwa, E. J. and Aloo, P. A. (2015). Effects of dietary administration of stinging nettle (Urtica dioica) on the growth performance, biochemical, hematological and immunological parameters in juvenile and adult Victoria Labeo (Labeo victorianus) challenged with Aeromonas hydrophila. Fish and Shellfish Immunology, 44(2) : 533-541.

Nya, E. J. and Austin, B. (2009). Use of dietary ginger, Zingiber officinale Roscoe, as an immunostimulant to control Aeromonas hydrophila infections in rainbow trout, Oncorhynchus mykiss (Walbaum). Journal of Fish Diseases, 32(11) : 971-977

Obikaonu, H. O.; Okoli, I. C.; Opara, M. N.; Okoro, V. M. O.; Ogbuewu, I. P.; Etuk, E. B. and Udedibie, A. B. I. (2012). Haematological and serum biochemical indices of starter broilers fed leaf meal of neem (Azadirachta indica). Journal of Agriculture Technology, 8(1) : 71-79.

Pandit, N. P. and Nakamura, M. (2010). Effect of high temperature on survival, growth and feed conversion ratio of Nile Tilapia, Oreochromis niloticus. Our Nature, 8(1) : 219-224. 
Pratheepa, V. and Sukumaran, N. (2014). Effect of Euphorbia hirta plant leaf extract on immunostimulant response of Aeromonas hydrophila infected Cyprinus carpio. Peer J., 2 : 671.

Pratheepa, V.; Ramesh, S. and Sukumaran, N. (2010). Immunomodulatory effect of Aegle marmelos leaf extract on freshwater fish Cyprinus carpio infected by bacterial pathogen Aeromonas hydrophila. Pharmaceutical Biology, 48(11): 1224-1239.

Rajbanshi, K. G. (2002). Zoo-geographical distribution and the status of cold water fish of Nepal. In : Cold water fisheries in the transHimalayan countries (eds. Petr, T. and Swar, D. B.). FAO Fisheries Technical Paper. No. 431 Rome FAO, p. 376.

Ringo, E. and Song, S. K. (2016). Application of dietary supplements (synbiotics and probiotics in combination with plant products and glucans) in aquaculture. Aquaculture Nutrition, 22(1) : 4-24.

Sahu, S.; Das, B. K.; Pradhan, J.; Mahopatra, B. C.; Mishra, B. K. and Sarangi, N. (2007). Effect of Mangifera indica kernel as a feed additive on immunity and resistance to Aeromonas hydrophila in Labeo rohita fingerlings. Fish and Shellfish Immunology, 23: $109-118$.

Schreck, C. B.; Contreras-Sanchez, W. and Fitzpatrick, M. S. (2001). Effects of stress on fish reproduction, gamete quality and progeny. Aquaculture, 197(1-4) : 3-24.

Shalaby, A. M.; Khattab, Y. A. and Abdel Rahman, A. M. (2006). Effects of Garlic (Allium sativum) and chloramphenicol on growth performance, physiological parameters and survival of Nile tilapia (Oreochromis niloticus). Journal of Venomous Animals and Toxins including Tropical Diseases, 12(2) : 172-201.

Sheikhlar, A.; Alimon, A. R.; Daud, H.; Saad, C. R.; Webster, C. D.; Meng, G. Y. and Ebrahimi, M. (2014). White mulberry (Morus alba) foliage methanolic extract can alleviate Aeromonas hydrophila infection in African Catfish (Clarias gariepinus), Scientific World Journal.

Sudova, E.; Piakova, V.; Kroupova, H.; Pijáek, M. and Svobodova, Z. (2009). The effect of praziquantel applied per os on selected haematological and biochemical indices in common carp (Cyprinus carpio L.). Fish Physiology and Biochemistry, 35(4) : 599.

Tacon, A. G. (1987). The nutrition and feeding of farmed fish and shrimp; a training manual. 1: The essential nutrients. p. 15.

Van Doan, H.; Hoseinifar, S. H.; Dawood, M. A. O.; Chitmanat, C. and Tayyamath, K. (2017). Effects of Cordyceps militaris spent mushroom substrate and Lactobacillus plantarum on mucosal, serum immunology and growth performance of Nile tilapia (Oreochromis niloticus). Fish and Shellfish Immunology, 70 : 87-94.

Vico, G. D.; Guida, V. and Carella, F. (2018). Urtica dioica (Stinging Nettle) : A neglected plant with emerging growth promoter/ immunostimulant Properties for farmed Fish. Frontiers in Physiology, $9: 285$.

Wagner, E. J.; Intelmann, S. S. and Routledge, M. D. (1996). The effects of fry rearing density on hatchery performance, fin condition, and agonistic behavior of rainbow trout Oncorhynchus mykiss fry. Journal of the World Aquaculture Society, 27(3) : 264-274.

Wunderlich, A. C.; de Oliveira Penha Zica, E.; dos Santos Ayres, V. F.; Guimaraes, A. C. and Takeara, R. (2017). Plant-derived compounds as an alternative treatment against parasites in fish farming : A review. In : Natural Remedies in the Fight against Parasites (eds H. Khater, M. Govindarajan and G. Benelli), p. 246

Yan, J.; Guo, C.; Dawood, M. A. O. and Gao, J. (2017). Effects of dietary chitosan on growth, lipid metabolism, immune response and antioxidant-related gene expression in Misgurnus anguillicaudatus. Beneficial Microbes, 8(3) : 439-449.

Yarahmadi, P.; Kolangi Miandare, H. and Hoseinifar, S. H. (2016). Haemato immunological and serum biochemical parameters, intestinal histomorphology and growth performance of rainbow trout (Oncorhynchus mykiss) fed dietary fermentable fiber (Vitacel $\mathbb{R}$ ). Aquaculture Nutrition, 22(5) : 1134-1142. 